\title{
GRATIFIKASI PELAYANAN SEKSUAL SEBAGAI TINDAK PIDANA KORUPSI
}

\section{Mardiana Arsjad}

Universitas Borneo Tarakan, Kalimantan Utara

Email:

\begin{abstract}
This thesis research aims to analyze one of the types of criminal acts of corruption contained in Law Number 31 Year 1999 on the Eradication of Corruption which is amended by Law Number 20 Year 2001, which is about Gratification, in particular the provision of sexual service gifts in some cases of corruption. The issues raised in this study are whether the provision of sexual services received by public servants or state officials can be categorized as gratification and become a criminal act corruption. This study also aims to analyze the provision and regulation of legal sanctions for perpetrators of the gratification of sexual services in Indonesia

This study uses the type of normative legal research (normative legal research) because it is still less clear about the regulation of gratification of sexual services as one of the criminal acts of corruption. The approach used in this study is the approach of legislation and conceptual aproach.

Legal sanctions for Civil Servants and State Officials who commit corruption in accepting the gratification of sexual services may be charged under Article 5 paragraph (2), Article 12 letters a and b or Article 12B of Law Number 31 Year 1999 juncto Law Number 20 of 2001 when it meets its elemental elements. As for the gratification giver can be charged with Article 5 paragraph (1) of Law Number 31 Year 1999 juncto Law Number 20 Year 2001 and the sanction that can be applied to the object of sexual gratification law (women giving sex service) can be charged with article 15 Law Number 31 Year 1999 juncto Law Number 20 Year 2001. The recipients of gratification of sexual services and women who become the object of sexual services and the recipients of sexual services may also be charged under article 284 of the Criminal Code of moral decency if both fulfill the elements in the article.
\end{abstract}

Keywords : Gratification of Sexual Services, Corruption, Proof, Legal sanctions

\section{A. PENDAhuluan}

Pada era pemerintahan saat ini, bangsa Indonesia sudah banyak mengalami perkembangan dan perubahan, baik perubahan sistem politik, perubahan di sektor ekonomi sampai reformasi birokrasi . Reformasi birokrasi terutama mengedepankan masalah tentang bagaimana pegawai negeri dan penyelenggara negara dapat menjalankan prinsip integritas, 
prinsip akuntabilitas, serta menjalankan kode etik profesinya dalam melaksanakan tugas dan fungsinya sebagai aparat pemerintah . Namun pada kenyataannya masih banyak aparatur pemerintah yang berperilaku negatif, menyimpang dari etika, berlaku korup serta melakukan praktek - praktek kolusi dan nepotisme. Reformasi birokrasi dilaksanakan dengan harapan dapat meminimalisir masalah - masalah tersebut . Reformasi birokrasi ini diharapkan juga dapat memberikan solusi tentang perbaikan sistem penggajian dan peningkatan tunjangan kesejahteraan. Aparatur pemerintah bisa terhindar dari perilaku praktek - praktek korupsi, kolusi, dan nepotisme, karena dianggap penghasilannya sudah relatif mencukupi kebutuhan hidup sehari-hari dan untuk masa depannya. Tapi ternyata perilaku korupsi terus saja terjadi walaupun gaji dan tunjangan aparatur pemerintah relatif sudah memadai. Karena keserakahan dan ketamakan, sehingga praktek - praktek korupsi, kolusi dan nepotisme tetap saja berkembang dan berlangsung pada tatanan pemerintahan sejak dulu sampai sekarang.

Korupsi, satu kata yang hampir setiap hari kita baca dan dengar baik di media massa maupun media elektronik. Pelaku korupsi bahkan lebih terkenal dari selebriti atau artis terkenal yang setiap saat ditayangkan di televisi. Korupsi sudah seperti penyakit kronis yang memerlukan penanganan khusus untuk memberantasnya. Upaya pemberantasan korupsi yang dilakukan saat ini tidak hanya sebatas penindakan atau refresif tapi juga secara komprehensif melalui tindakan preventif atau pencegahan . Berbagai strategi pencegahan telah dilakukan oleh negara dengan menerbitkan undang -undang dan peraturan - peraturan tentang korupsi. Strategi strategi pencegahan juga dilakukan oleh lembaga Komisi Pemberantasan Tindak Pidana Korupsi (KPK), lembaga-lembaga swadaya masyarakat, organisasi-organisasi kemasyarakatan lainnya yang berkomitmen untuk melakukan pemberantasan tindak pidana korupsi di Indonesia. 
Ada beberapa butir penerapan program pencegahan korupsi yang dilakukan, terutama yang ditujukan kepada pegawai negeri, sebagai berikut :

1. Penandatanganan dokumen Pakta Integritas;

2. Pemenuhan kewajiban LHKPN;

3. Pemenuhan Akuntabilitas Kinerja;

4. Pemenuhan kewajiban laporan keuangan;

5. Penerapan Disiplin PNS;

6. Penerapan Kode Etik Khusus;

7. Penerapan kebijakan pelayanan publik;

8. Penerapan Wistleblower System Tindak Pidana Korupsi;

9. Pengendalian Gratifikasi;

10. Penanganan benturan kepentingan;

11. Kegiatan pendidikan / pembinaan dan promosi anti korupsi.

12. Pelaksanaan saran perbaikan dari BPK/KPK/APIP;

13. Penerapan kebijakan purna tugas;

14. Penerapan kebijakan pelaporan transaksi tidak wajar;

15. Rekrutmen secara terbuka;

16. Promosi jabatan secara terbuka;

17. Mekanisme pengaduan masyarakat;

18. Pelaksanaan E-procurement;

19. Pengukuran kinerja individu;

20. Keterbukaan Informasi Publik. ${ }^{1}$

Korupsi merupakan bahaya laten dan telah menjadi kejahatan yang luar biasa ( extra ordinary crime ) karena korupsi berpotensi dilakukan oleh siapa saja, kerugian yang ditimbulkan sangat besar dan meluas ( snowball atau domino effect), target dan korbannya juga bisa siapa saja (random

${ }^{1}$ Kementerian Pendayagunaan Aparatur Negara dan Reformasi Birokrasi, Sosialisasi Pedoman Pembangunan Zona Integritas Menuju WBK dan WBBM, Peraturan Menteri PAN-RB Nomor 60 Tahun 2012, Kemenpan-rb, Jakarta, 2013 
target/random victim) , terorganisasi atau oleh organisasi dan bersifat lintas negara. Karenanya pemberantasannya pun harus dilakukan dengan cara-cara yang luar biasa. ${ }^{2}$

Korupsi merupakan kejahatan yang mempunyai akibat sangat kompleks dan sangat merugikan keuangan Negara, dan di Indonesia sendiri korupsi telah

menjadi masalah serius bagi bangsa Indonesia, karena telah merambah ke seluruh lini kehidupan masyarakat yang dilakukan secara sistematis, sehingga

memunculkan stigma negatif bagi negara dan bangsa Indonesia di dalam pergaulan masyarakat Indonesia. ${ }^{3}$

Korupsi bukan lagi kejahatan pidana biasa tapi memang sudah sangat merusak sendi-sendi kehidupan bangsa. Tidak hanya memberangus kehidupan ekonomi bangsa tapi lebih dari itu. Kejahatan korupsi merusak mental bangsa Indonesia, korupsi membentuk manusia-manusia yang bermental pengemis. Praktek-praktek korupsi sudah merebak ke berbagai kalangan dan di berbagai unsur. Tidak hanya dilakukan oleh penyelenggara negara dan pegawai negeri tapi juga di kalangan pengusaha. Pelaku korupsi juga tidak memandang jenis kelamin dan usia. Laki-laki dan perempuan, usia muda dan tua, banyak yang terlibat dalam kejahatan korupsi. Bahkan berbagai kalangan menilai bahwa

korupsi telah menjadi bagian dari kehidupan, menjadi suatu sistem dan menyatu dengan penyelenggarakan pemerintahan Negara. ${ }^{4}$

Undang-Undang Nomor 20 Tahun 2001 Tentang Perubahan Atas UndangUndang Nomor 31 Tahun 1999 Tentang Pemberantasan Tindak Pidana

\footnotetext{
${ }^{2}$ Saya Perempuan Anti Korupsi (SPAK), Buku Panduan Game SPAK, Mengenal Korupsi, AIPJ, Jakarta, 2015.h.3

${ }^{3}$ Chaerudin, S.H, M.H, Syaiful Ahmad Dinar,S.H,M.H dan Syarif Fadillah,S.H,M.H, Strategi Pencegahan dan Penegakan Tindak Pidana Korupsi, Refika Aditama, Bandung, 2008, h 1.

${ }^{4}$ Ibid
} 
Korupsi mengatur pasal-pasal tentang perbuatan/ tindakan/kebijakan yang bisa dikenakan pidana mati, pidana penjara, dan pidana denda karena korupsi.

Salah satu pasal dalam Undang-Undang Nomor 31 Tahun 1999 tentang Pemberantasan Tindak Pidana Korupsi juncto Undang-Undang Nomor 20 Tahun 2001 Tentang Perubahan Atas Undang-Undang 31 Tahun 1999 Tentang Pemberantasan Tindak Pidana Korupsi yang tercantum dalam pasal $12 \mathrm{~B}$ mengatur tentang pemberian gratifikasi kepada pegawai negeri atau penyelenggara negara. Dari pembahasan tersebut yang akan menjadi fokus dalam penelitian dan penulisan ini adalah tentang gratifikasi, dalam hal ini secara khusus akan membahas tentang gratifikasi pelayanan seksual sebagai tindak pidana korupsi.

Gratifikasi menjadi unsur penting dalam sistem dan mekanisme pertukaran hadiah. Sehingga kondisi ini memunculkan banyak pertanyaan pada penyelenggara negara, pegawai negeri dan masyarakat, seperti apa yang dimaksud dengan gratifikasi dan apakah gratifikasi sama dengan pemberian hadiah yang umum dilakukan dalam masyarakat ataukah setiap gratifikasi yang diterima oleh penyelenggara negara atau pegawai negeri merupakan perbuatan yang berlawanan dengan hukum, lalu bagaimana saja bentuk gratifikasi yang dilarang maupun yang diperbolehkan. Semua itu merupakan pertanyaan-pertanyaan yang sering dijumpai dalam setiap persoalan menyangkut gratifikasi. ${ }^{5}$

Pada perkembangannya saat ini pemberian hadiah / gratifikasi tidak hanya sebatas pemberian uang atau barang barang mewah, diskon, fasilitas perjalanan, dan lain-lain tapi juga mulai disuguhkannya jasa pelayanan seksual yang dikenal dengan istilah jasa pinggul atau uang selimut sebagai suatu pemberian atau gratifikasi pelayanan seksual terhadap pegawai negeri sipil atau penyelenggara Negara . Pemberian layanan atau fasilitas "seksual “ ini tentunya juga sama seperti pemberian atau gratifikasi lainnya yakni bertujuan untuk memudahkan dan memuluskan berbagai proyek kegiatan

\footnotetext{
${ }^{5}$ Doni Muhardiansyah et al, Buku Saku: Memahami Gratifikasi, Cet. Ke-1, Komisi Pemberantasan Korupsi, Jakarta, 2010, h.1
} 
atau untuk mempengaruhi kebijakan dari pejabat Negara atau penyelenggara Negara.

Penjelasan pasal 12 B ayat (1) Undang- Undang Nomor 31 Tahun 1999 juncto Undang - Undang Nomor 20 Tahun 2001 Tentang Pemberantasan Tindak Pidana Korupsi mendefenisikan gratifikasi sebagai pemberian dalam arti luas, yakni meliputi pemberian uang, barang, rabat (diskon), komisi, pinjaman tanpa bunga, tiket perjalanan, fasilitas penginapan, perjalanan wisata, pengobatan cuma-cuma, dan fasilitas lainnya. Gratifikasi tersebut baik yang diterima di dalam negeri maupun di luar negeri, dan yang dilakukan dengan menggunakan sarana elektronik atau tanpa elektronik. Defenisi ini belum menjelaskan secara rinci tentang pemberian layanan atau fasilitas seksual sebagai salah satu bentuk gratifikasi. Hal ini dapat menunjukkan kelemahan dan kekaburan rumusan hukum dari penjelasan tersebut. Masih terdapat perbedaan pendapat mengenai kata "fasilitas lainnya " apakah itu menjadi dasar yang kuat untuk menyebutkan bahwa pelayanan seksual yang diberikan kepada pejabat atau penyelenggara negara masuk dalam kategori tersebut.

Belum tegasnya pengaturan mengenai gratifikasi layanan seksual dalam penjelasan pasal 12 B ayat (1) Undang-Undang Nomor 31 Tahun 1999 juncto Undang-Undang Nomor 20 Tahun 2001 tentang Pemberantasan Tindak Pidana Korupsi tentunya aturan ini juga belum secara tegas merumuskan sanksi yang pantas dijatuhkan bagi pelaku baik pemberi maupun penerima layanan gratifikasi seksual tersebut dan juga dalam hal ini sanksi pidana bagi perempuan pemberi layanan seksual tersebut.

\section{B. Rumusan Masalah}

1. Apakah gratifikasi pelayanan seksual sebagai tindak pidana korupsi ?

2. Bagaimana pembuktian dan pengaturan sanksi hukum pelaku gratifikasi pelayanan seksual di Indonesia ?

\section{Metode Penelitian}


Berdasarkan permasalahan yang diteliti maka penulis menggunakan jenis penelitian hukum normatif (normative legal research). Penelitian hukum normatif adalah penelitian yang menggunakan norma hukum positif yang dilakukan dengan cara mempelajari dan mengkaji peraturan perundang-undangan yang berlaku atau diterapkan terhadap suatu permasalahan hukum tertentu serta peraturan lain yang berkenaan dengan permasalahan yang akan diteliti

\section{PEMBAHASAN}

\section{Gratifikasi Pelayanan Seksual Sebagai Tindak Pidana Korupsi}

Undang-Undang Nomor 31 Tahun 1999 juncto Undang-Undang Nomor 20 Tahun 2001 Tentang Pemberantasan Tindak Pidana Korupsi mengatur pasal-pasal tentang perbuatan/tindakan/kebijakan yang bisa dikenakan pidana mati, pidana penjara, dan pidana denda karena korupsi. Berdasarkan pasal-pasal tersebut, korupsi dirumuskan dalam 30 (tiga puluh) bentuk/jenis tindak pidana korupsi. Ketiga puluh pasal tersebut tercakup dalam pasal 2 sampai dengan pasal 13 Undang-Undang Nomor 31 Tahun 1999 juncto Undang-Undang Nomor 20 Tahun 2001 Tentang Pemberantasan Tindak Pidana Korupsi.

Ketiga puluh bentuk/jenis delik tindak pidana korupsi, 2 jenis delik mengatur tentang perbuatan yang merugikan keuangan negara atau perekonomian negara, sedangkan 28 lainnya mengatur tentang perilaku penyelenggara Negara terkait dengan kekuasaannya. Ketiga puluh bentuk/jenis tindak pidana korupsi dan tindak pidana yang berkaitan dengan korupsi berdasarkan Undang-Undang Tindak Pidana Korupsi dapat dikelompokkan sebagai berikut ${ }^{6}$ :

1. Melawan hukum untuk memperkaya diri dan dapat merugikan keuangan negara ;

2. Menyalahgunakan kewenangan untuk kepentingan diri sendiri dan dapat

\footnotetext{
${ }^{6}$ Tim Penulis Buku Pendidikan Anti Korupsi, Pendidikan Korupsi Untuk Perguruan Tinggi, Anti Korupsi, Kementerian Pendidikan dan Kebudayaan RI, Direktorat Jenderal Pendidikan Tinggi, Bagian Hukum Kepegawaian, Jakarta, 2011, h 27 et seq.
} 
merugikan keuangan Negara ;

3. Menyuap pegawai negeri ;

4. Memberi hadiah kepada pegawai negeri karena jabatannya ;

5. Pegawai negeri menerima suap ;

6. Pegawai negeri menerima hadiah yang berhubungan dengan jabatannya ;

7. Menyuap hakim ;

8. Menyuap advokat ;

9. Hakim dan advokat menerima suap ;

10. Pegawai negeri menggelapkan uang atau membiarkan penggelapan ;

11. Pegawai negeri memalsukan buku untuk pemeriksaan administrasi ;

12. Pegawai negeri merusakkan bukti ;

13. Pegawai negeri membiarkan orang lain merusakkan bukti ;

14. Pegawai negeri membantu orang lain merusakkan bukti ;

15. Pegawai negeri memeras ;

16. Pegawai negeri memeras pegawai yang lain ;

17. Pemborong berbuat curang ;

18. Pengawas proyek membiarkan perbuatan curang ;

19. Rekanan TNI/Polri berbuat curang ;

20. Pengawas rekanan TNI/Polri membiarkan perbuatan curang ;

21. Penerima barang TNI/Polri membiarkan perbuatan curang ;

22. Pegawai negeri menyerobot tanah negara sehingga merugikan orang lain ;

23. Pegawai negeri turut serta dalam pengadaan yang diurusnya ;

24. Pegawai negeri menerima gratifikasi dan tidak lapor KPK ;

25. Merintangi proses pemeriksaan ;

26. Tersangka tidak memberikan keterangan mengenai kekayaannya ;

27. Bank yang tidak memberikan keterangan rekening tersangka ;

28. Saksi atau ahli yang tidak memberi keterangan atau memberi keterangan palsu ;

29. Orang yang memegang rahasia jabatan tidak memberikan keterangan atau memberi keterangan palsu; 
30. Saksi yang membuka identitas pelapor

Jenis / bentuk tindak pidana korupsi di atas dapat dirincikan ke dalam 7 kelompok yaitu : Korupsi yang berkaitan dengan Kerugian Negara, Korupsi yang berkaitan dengan Suap Menyuap, Korupsi yang berkaitan dengan Perbuatan Pemerasan, Korupsi yang berkaitan dengan Perbuatan Curang, Korupsi yang Terkait dengan Benturan Kepentingan dalam Pengadaan, Korupsi yang Terkait dengan Gratifikasi

\subsection{Karakteristik Tindak Pidana Korupsi}

Pembahasan tentang karakteristik tindak pidana korupsi belum banyak diuraikan dalam beberapa tulisan atau literatur. Namun dari beberapa konsep defenisi tentang korupsi atau tindak pidana korusi menyimpulkan bahwa korupsi adalah perbuatan yang tidak baik, perbuatan yang tidak terpuji, perbuatan untuk memperkaya diri sendiri dan orang lain juga korporasi dengan cara - cara yang melanggar aturan yang merugikan negara atau keuangan negara yang dilakukan oleh orang - orang yang memiliki kewenangan atau kekuasaan.

Untuk menjelaskan tentang karakteristik tindak pidana korupsi, penulis mengutip rumus tentang korupsi yang dikemukakan oleh Robert Klitgard sebagai berikut :

$\mathrm{C}=\mathrm{D}+\mathrm{M}-\mathrm{A}$

$\mathrm{C}=$ Corruption

$\mathrm{D}=$ Discretion

$\mathrm{M}=$ Monopoly

$\mathrm{A}=$ Accountability $^{7}$

Dari rumus yang dikemukakan tersebut dapat dipahami bahwa korupsi akan terjadi jika seseorang yang memiliki kewenangan untuk mengambil kebijakan dan menguasai pemerintahan serta mengabaikan

\footnotetext{
${ }^{7}$ Lembaga Adminstrasi Negara. Modul Diklat Prajabatan Anti Korupsi. LAN. Jakarta. 2014,
} h. 16 
pertanggungjawaban yang seharusnya dilakukan. Pegawai negeri dan penyelenggara negara yang memiliki kewenangan sebagai pengambil kebijakan akan berpotensi melakukan kejahatan tindak pidana korupsi jika melaksanakan diskresi tanpa batas. Undang - Undang Nomor 30 Tahun 2014 Tentang Administrasi Pemerintahan pasal 1 angka 9 mendefenisikan diskresi sebagai keputusan dan/atau tindakan yang ditetapkan dan/ atau dilakukan oleh pejabat pemerintahan untuk mengatasi persoalan konkret yag dihadapi dalam penyelenggaraan pemerintahan dalam hal peraturan perundang-undangan yang memberikan pilihan, tidak mengatur, tidak lengkap atau tidak jelas dan /atau adanya stagnasi pemerintahan .

Salah satu karakteristik tindak pidana korupsi lainnya adalah minimnya akuntabilitas dari para penyelenggara negara dalam mempertanggungjawabkan kinerjanya kepada publik .

Akuntabilitas adalah kesesuaian antara aturan dan pelaksanaan kerja. Semua lembaga wajib mempertanggungjawabkan kinerjanya sesuai aturan main, baik dalam bentuk konvensi (de facto) maupun konstitusi (de jure), baik pada level budaya (individu dengan individu) maupun pada level lembaga. Lembaga - lembaga tersebut berperan dalam sektor bisnis, masyarakat, publik, maupun interaksi antara ketiga sektor tersebut ${ }^{8}$

Akuntabilitas merupakan kewajiban untuk memberikan pertanggungjawaban atau menjawab atau menerangkan kinerja atau tindakan seseorang/ badan hukum atau pimpinan organisasi kepada pihak yang memiliki hak atau kewenangan untuk meminta keterangan atau dipertanggungjawabkan ${ }^{9}$

\footnotetext{
${ }^{8}$ Ibid dikutip dari Nanang T. Puspito, Pendidikan Anti Korupsi Untuk Perguruan Tinggi, Bagian Hukum Kepegawaian, Direktorat Jenderal Pendidikan Tinggi, Kementerian Pendidikan dan Kebudayaan, Jakarta, 2011, h.81

${ }^{9}$ IGM Nurdjana, dalam Zudan Arif Fakhrullah, " Akuntabilitas Kebijakan Dan Pembudayaan Perilaku Anti Korupsi “, Jurnal Perspektif, Volume XVI No.2 , Edisi April 2011, h.109
} 
Akuntabilitas kinerja menjadi sesuatu yang sangat penting terutama bagi pegawai negeri atau penyelenggara negara. Seorang pegawai negeri atau penyelenggara negara dituntut untuk memberikan pertanggungjawaban kinerja, sesuai dengan tanggung jawab dan tugas pokok fungsi yang telah dibebankan kepadanya dalam organisasinya. Diawali dengan pertanggung jawaban atas semua proses kegiatan mulai perencanaan, pelaksanaan sampai tahap evaluasi. Dan tak kalah pentingnya juga harus memberikan pertanggungjawaban berupa laporan akuntabilitas pengelolaan dan penggunaan anggaran. Semua itu tentunya tidak hanya sebatas pertanggungjawaban kepada atasan tetapi secara moral setiap aparatur pemerintah harus bertanggung jawab dan mempertanggungjawabkan segala sikap dan perilakunya, segala keputusan dan kebijakan kepada masyarakat sebagai wujud tata kelola pemerintahan yang baik dan tentunya dengan menerapkan secara disiplin dan penuh tanggung jawab, prinsip akuntabilitas ini akan meminimalisir terjadinya praktek - praktek korupsi di lingkungan pemerintahan dan akan membawa dampak yang positif terhadap pelayanan publik.

\subsection{Karakteristik Gratifikasi}

Terminologi Gratifikasi baru dikenal dalam ranah hukum pidana Indonesia sejak tahun 2001 melalui Undang-Undang Nomor 20 Tahun 2001 tentang Perubahan atas Undang-Undang Nomor 31 Tahun 1999 tentang Pemberantasan Tindak Pidana Korupsi. Pada Pasal 12 B dan 12 C UndangUndang Pemberantasan Tindak Pidana Korupsi tersebut diatur mengenai delik gratifikasi, mengatur ancaman pidana bagi setiap pegawai negeri/penyelenggara Negara yang menerima segala bentuk pemberian yang tidak sah dalam pelaksanaan tugasnya, atau yang diistilahkan sebagai gratifikasi yang dianggap suap dan tidak melaporkannya pada KPK dalam jangka waktu paling lama 30 hari kerja. 
Pegawai negeri yang dimaksud sebagaimana diuraikan dalam pasal 1 ayat (2) Undang - Undang Nomor 31 Tahun 1999 Tentang Pemberantasan Tindak Pidana Korupsi meliputi :

a. Pegawai negeri sebagaimana undang - undang tentang kepegawaian,

b. Pegawai negeri sebagaimana dimaksud dalam Kitab Undang - Undang Hukum Pidana;

c. Orang yang menerima gaji atau upah dari keuangan negara atau daerah;

d. Orang yang menerima gaji atau upah dari suatu korporasi yang menerima bantuan dari keuangan negara atau daerah, atau

e. Orang yang menerima gaji atau upah dari korporasi lain yang mempergunakan modal atau fasilitas dari negara atau masyarakat.

Dalam buku Pedoman Pengendalian Gratifikasi yang diterbitkan oleh Komisi Pemberantasan Tindak Pidana Korupsi menjelaskan secara rinci tentang siapa saja yang termasuk dalam kategori penyelenggara negara. Penyelenggara Negara adalah Pejabat Negara yang menjalankan fungsi eksekutif, legislatif, atau yudikatif dan pejabat lain yang fungsi dan tugas pokoknya berkaitan dengan penyelenggaraan Negara sesuai dengan ketentuan peraturan perundang-undangan yang berlaku (Pasal 1 angka (1) UU Nomor 28 Tahun 1999).

Pasal 12 B Undang - Undang Nomor 20 Tahun 2001 Tentang Perubahan Atas Undang - Undang Nomor 31 Tahun 1999 Tentang Pemberantasan Tindak Pidana Korupsi menyatakan bahwa :

1. Setiap gratifikasi kepada pegawai negeri atau penyelenggara Negara dianggap pemberian suap, apabila berhubungan dengan jabatannya dan yang berlawanan dengan kewajiban atau tugasnya, dengan ketentuan sebagai berikut :

a. Yang nilainya Rp. 10.000.000,00 (sepuluh juta rupiah) atau lebih, pembuktian bahwa gratfikasi tersebut bukan merupakan suap dilakukan oleh penerima gratifikasi 
b. Yang nilainya kurang dari Rp. 10.000.000,00 (sepuluh juta rupiah), pembuktian bahwa gratifikasi tersebut suap dilakukan oleh penuntut umum.

2. Pidana bagi pegawai negeri atau penyelenggara Negara sebagaimana dimaksud dalam ayat (1) adalah pidana penjara seumur hidup atau pidana penjara paling singkat 4 (empat) tahun dan paling lama 20 (dua puluh) tahu, dan pidana denda paling sedikit Rp. 200.000.000,00 (dua ratus juta rupiah) paling banyak Rp. 1.000.000.000,00 (satu miliar rupiah)

Pasal 12 C menyatakan :

1. Ketentuan sebagaimana dimaksud dalam pasal $12 \mathrm{~B}$ ayat (1) tidak berlaku, jika penerima melaporkan gratifikasi yang diterimanya kepada Komisi Pemberantasan Tindak Pidana Korupsi.

2. Penyampaian laporan sebagaimana dimaksud dalam ayat (1) wajib dilakukan oleh penerima gratifikasi paling lambat 30 (tigapuluh) hari kerja terhitung sejak tanggal gratifikasi tersebut diterima.

Dalam pasal 16 Undang - Undang Nomor 30 Tahun 2002 Tentang Komisi Pemberantasan Tindak Pidana Korupsi mewajibkan kepada pegawai negeri dan penyelenggara Negara untuk melaporkan setiap gratifikasi yang diterima. Dihubungkan dengan Penjelasan Pasal 16, maka gratifikasi yang wajib dilaporkan adalah gratifikasi sebagaimana dimaksud pada Pasal 12 B, yaitu gratifikasi yang dianggap suap.

Karakteristik gratifikasi yang tidak wajib dilaporkan, yaitu :

1. Berlaku umum, yaitu suatu kondisi pemberian yang diberlakukan sama dalam hal jenis, bentuk, persyaratan atau nilai, untuk semua peserta dan memenuhi prinsip kewajaran atau kepatutan;

2. Tidak bertentangan dengan peraturan perundang-undangan yang berlaku; 
3. Dipandang sebagai wujud ekspresi, keramah-tamahan, penghormatan dalam hubungan sosial antar sesama dalam batasan nilai yang wajar; atau,

4. Merupakan bentuk pemberian yang berada dalam ranah adat istiadat, kebiasaan, dan norma yang hidup di masyarakat dalam batasan nilai yang wajar. 10

\subsection{Identifikasi Gratifikasi Pelayanan Seksual Sebagai Tindak Pidana Korupsi}

Dari penjelasan di atas dan uraian tentang unsur-unsur delik gratifikasi dan /atau suap hanya dibatasi pemberian uang atau barang serta fasilitas. Padahal dalam perkembangannya saat ini pemberian atau hadiah yang diberikan kepada seseorang tidak hanya sebatas uang atau barang (benda mati), tapi juga pemberian atau hadiah berupa hewan hewan peliharaan (beberapa jenis hewan yang harganya relatif mahal ) atau pemberian hadiah berupa kesenangan dan layanan seksual seperti yang saat ini semakin marak dibicarakan.

Meskipun belum dapat dibuktikan secara kasat mata, praktek praktek pemberian jasa layanan seksual ini sebenarnya telah lama terjadi bahkan jauh sebelum adanya peraturan tentang korupsi dan gratifikasi. Tidak jarang hal itu diberikan untuk memperlancar urusan transaksi dalam bisnis oleh para pengusaha maupun transaksi politik oleh para penyelenggara negara. Para pengusaha tanpa mengindahkan moral dan etika menjadikan layanan seksual sebagai salah satu langkah untuk memuluskan bisnis mereka . Salah satu kasus yang pernah terjadi adalah godaan suap yang pernah dialami oleh mantan Kapolri Hoegeng Imam Santosa, Pria kelahiran Pekalongan 14 Oktober 1921. Beliau pernah dirayu seorang pengusaha cantik yang terlibat kasus penyelundupan. Wanita ini berusaha meminta agar kasusnya tidak berlanjut ke pengadilan. Berbagai hadiah mewah dikirim tapi Hoegeng

${ }^{10}$ Komisi Pemberantasan Tindak Pidana Korupsi, Pedoman Pengendalian Gratifikasi, KPK, Jakarta, 2015. h.25 
menolak mentah-mentah. Yang membuat Hoegeng heran malah koleganya dari kepolisian dan kejaksaan memintanya untuk melepaskan wanita itu. Hoegeng heran kenapa banyak pejabat ingin menolong pengusaha wanita tersebut. Belakangan Hoegeng mendapat kabar bahwa wanita pengusaha itu tidak segan-segan "tidur" dengan pejabat demi memuluskan aksi penyelundupannya. ${ }^{11}$

Dalam penjelasan pasal $12 \mathrm{~B}$ istilah pelayanan seks memang tidak tercantum , hanya ada kata " fasilitas lain” di mana dalam undang undang pemberantasan tindak pidana korupsi tersebut tidak menjelaskan secara rinci apa yang dimaksud dengan "fasilitas lain".

Pengertian fasilitas dalam Kamus Besar Bahasa Indonesia adalah sarana untuk melancarkan pelaksanaan fungsi. Hj.Zakiah Daradjat, salah seorang pakar psikologi Islam berpendapat bahwa fasilitas adalah segala sesuatu yang bisa mempermudah upaya serta memperlancar kerja dalam rangka mencapai suatu tujuan tertentu. ${ }^{12}$ Dari pengertian tersebut, gratifikasi pelayanan seksual bisa disebut sebagai "fasilitas" karena terdapat unsur "mempermudah" dan "memperlancar". Gratifikasi seksual disuguhkan untuk memperlancar dan mempermudah keinginan dari para pemberi gratifikasi. Dengan demikian jika gratifikasi seksual dapat diartikan sebagai "fasilitas lainnya" maka gratifikasi seksual dapat dikategorikan sebagai tindak pidana korupsi dan dapat dijatuhi sanksi pidana dengan mengacu kepada peraturan perundang-undangan yang ada yaitu yang tercantum dalam Undang -Undang Nomor 20 Tahun 2001 Tentang Perubahan Undang - Undang Nomor 31 Tahun 1999 Tentang Pemberantasan Tindak Pidana Korupsi.

Gratifikasi atau pemberian jasa pelayanan seksual dapat dianggap suap jika pemberian dalam bentuk "kesenangan" dan "kenikmatan" itu

\footnotetext{
${ }^{11}$ Ramadhan KH dan Abrar Yusra, Hoegeng : Polisi Idaman dan Kenyataan, Sinar Harapan, Jakarta, 1994.

12 Pengertian Fasilitas, www.pengertianmenurutparaahli.net....diakses pada tanggal 25 Juli 2017, pukul 20.10
} 
diterima oleh pegawai negeri atau penyelenggara Negara, berhubungan dengan jabatannya dan yang berlawanan dengan kewajiban atau tugasnya. Dengan demikian gratifikasi pelayanan seksual dapat dikategorikan sebagai tindak pidana korupsi. Meskipun dalam putusan putusan hakim pada kasus korupsi yang terindikasi atau terdapat unsur gratifikasi pelayanan seksual belum menjatuhkan vonis hukum sesuai sanksi pidana yang terdapat dalam Undang- Undang Tindak Pidana Korupsi.

\section{Pembuktian dan Pengaturan Sanksi Hukum Pelaku Gratifikasi}

\section{Pelayanan Seksual di Indonesia}

\subsection{Pembuktian Gratifikasi Pelayanan Seksual Berdasarkan Hukum Pidana di Indonesia}

Pemberian atau hadiah yang diterima oleh pegawai negeri atau penyelenggara Negara adalah tindakan yang tidak diperbolehkan dan bisa dikategorikan gratifikasi apabila pemberian tersebut dapat mempengaruhi keputusan atau kebijakan dan dapat mempengaruhi integritas, independensi dan obyektifitas dari penerima hadiah tersebut.

Pemberian yang menyenangkan misalnya disuguhi perempuan cantik untuk dikencani beserta fasilitas menginapnya di hotel berbintang. Hal ini yang diperkirakan akan menarik kehendak pegawai negeri untuk berbuat atau tidak berbuat sesuai dengan kehendak si pembuat atau pemberi suap. ${ }^{13}$

Gratifikasi seks atau layanan "seks" jika ditinjau dari segi moral maka tindakan itu sangat melecehkan martabat seorang wanita (entah melalui sebuah konsensus bisnis atau pun karena keterpaksaan). Selain itu juga tindakan untuk menggunakan tubuh wanita atau perempuan sebagai imbalan atau suap kepada seseorang adalah sebuah pelanggaran terhadap

\footnotetext{
${ }^{13}$ Adami Chazawi, Hukum Pidana Korupsi di Indonesia (Edisi Revisi), Rajagrafindo Persada, Jakarta, 2016, h. 77
} 
hak ketubuhan perempuan sebagai "sesuatu" atau "benda" yang mempunyai nilai ekonomis. ${ }^{14}$

Pembuktian tindak pidana merupakan salah satu proses dari sistem penegakan hukum pidana. Pembuktian sebagai titik fokus pertanggung jawaban hakim dalam memutuskan suatu perkara . Putusan yang ditetapkan oleh hakim sangat tergantung dari proses pembuktian dan alat bukti yang ada.

Asas Lex Specialis Derogat Lex Generalis berlaku dalam ketentuan Pasal 12 B ayat (1) huruf a Undang-Undang Nomor 20 Tahun 2001 karena merupakan penyimpangan dari ketentuan Kitab Undang-Undang Hukum Acara Pidana (KUHAP). Menurut Pasal 137 KUHAP, jaksa penuntut umumlah yang harus membuktikan apakah terdakwa melakukan tindak pidana. Sedangkan pada Pasal 66 KUHAP ditegaskan bahwa tersangka atau terdakwa tidak dibebani kewajiban pembuktian. Dalam Pasal 12 B ayat (1) huruf a, yang diberi beban pembuktian bahwa gratifikasi yang nilainya Rp 10.000.000,00 (sepuluh juta rupiah) atau lebih adalah bukan merupakan suap dilakukan oleh penerima gratifikasi

Sistem pembuktian terbalik telah di terapkan dalam Undang - Undang Nomor 20 Tahun 2001. Pembuktian ini diberlakukan khusus pada tindak pidana korupsi pasal gratifikasi yang terkait dengan pasal penyuapan juga terkait tuntutan perampasan harta benda terdakwa yang diduga berasal dari salah satu tindak pidana dalam pasal 2, pasal 3, pasal 4, pasal 13, pasal 14, pasal 15, dan pasal 16 Undang- Undang Nomor 31 Tahun 1999, serta pasal 5 sampai dengan pasal 12 Undang-Undang Nomor 20 Tahun 2001.

Adapun alat bukti dalam tindak pidana korupsi, selain berdasarkan KUHAP pasal 184 ( keterangan saksi, keterangan ahli, surat, petunjuk, dan keteragan terdakwa ) juga berdasarkan Pasal 26 A Undang-Undang Nomor 20 Tahun 2001 sebagai berikut:

\footnotetext{
${ }^{14}$ Gail Hardy, "Kebutuhan Perempuan dalam Interaksi Sosial: Suatu Masalah Perempuan dalam Heterogenitas Kelompoknya", dalam Perempuan dan Politik Tubuh Fantastis, Kanisius, Yogyakarta, 1998, h.120.
} 
"Alat bukti yang sah dalam bentuk petunjuk sebagaimana dimaksud dalam pasal 188 ayat (2) Undang-Undang Nomor 8 Tahun 1981 tentang Hukum Acara Pidana, khusus untuk tindak pidana korupsi juga dapat diperoleh dari:

a. alat bukti lain yang berupa informasi yang diucapkan, dikirim, diterima, atau disimpan secara elektronik dengan alat optik atau yang serupa dengan itu , dan

b. dokumen, yakni setiap rekaman data atau informasi yang dapat dilihat, dibaca, dan atau didengar yang dapat dikeluarkan dengan atau tanpa bantuan suatu sarana, baik yang tertuang di atas kertas, benda fisik apapun selain kertas, maupun yang terekam secara elektronik, yang berupa tulisan, suara, gambar, peta, rancangan, foto, huruf, tanda, angka, atau perforasi yang memiliki makna.

Dari uraian di atas tentang dasar - dasar hukum pembuktian dalam tindak pidana korupsi terkait dengan gratifikasi, maka menurut pandangan penulis bahwa pembalikan beban pembuktian gratifikasi pelayanan seksual dapat merujuk pada pengenaan pembuktian pasal 12 B Undang-Undang Nomor 20 Tahun 2001. Pembuktian gratifikasi seksual bisa melalui kesaksian atau alat bukti lainnya. Di era komunikasi yang semakin berkembang, media komunikasi berupa SMS, email, dan sarana media sosial lainnya dapat menjadi alat bukti " petunjuk " yang dapat digunakan untuk menjerat pelaku gratfikasi pelayanan seksual.

Penjelasan pasal 12 B yang dimaksud "fasilitas lainnya" bisa lebih diperjelas dengan menambahkan beberapa item termasuk "pelayanan seksual”

Tidak bisa dipungkiri bahwa jasa atau tarif pelayanan seksual relatif cukup mahal terutama untuk konsumsi kalangan pejabat atau pengusaha. Dari tayangan di televisi tarif untuk jasa pelayanan seksual berkisar Rp. 5.000.000,00 (lima juta rupiah) sampai Rp. 10.000.000,00 (sepuluh juta rupiah) untuk kelas menengah sedangkan kelas atas (biasanya dari kalangan artis atau model) mendapat bayaran Rp. 
50.000.000,00 (lima puluh juta rupiah) sampai dengan Rp. 100.000.000,00 (seratus juta rupiah) bahkan lebih. Hal ini dapat menjadi acuan bahwa gratifikasi pelayanan seksual dapat dikonversikan dalam bentuk uang dan hal ini dapat dijadikan dasar dalam pembalikan beban pembuktian/pembuktian terbalik.

\subsection{Kebijakan Pidana dan Sanksi Hukum Terhadap Pelaku Gratifikasi Seksual}

Berdasarkan Undang-Undang Nomor 20 Tahun 2001 tentang Perubahan Undang-Undang Nomor 31 Tahun 1999 tentang Pemberantasan Tindak Pidana Korupsi, gratifikasi dapat dipidana apabila yang menerima hadiah adalah pegawai negeri atau penyelenggara negara. Namun belum ada kepastian hukum mengenai pemberian layanan seks sebagai salah satu bentuk gratifikasi. Kebijakan pidana atau ketentuan pidana tentang gratifikasi seksual dan sanksi hukumnya terhadap pelaku terutama "perempuan" yang menjadi pelaku layanan seksual memang belum diatur secara jelas dan terinci dalam undang-undang sampai saat ini.

Tak bisa dipungkiri bahwa praktek-praktek gratifikasi terutama pemberian layanan seksual tentu sangat bertentangan dengan nilai nilai agama dan nilai - nilai moral yang ada di masyarakat dan hal itu juga dapat merugikan negara karena indikasi dari pemberian itu adalah untuk mendapatkan kemudahan untuk menguntungkan pribadi atau golongan tertentu.

Selain tindak pidana umum, dikenal pula tindak pidana khusus yang diatur diluar KUHP, misalnya tindak pidana korupsi, tindak pidana ekonomi, dan lain-lain.15. Perbuatan gratifikasi dalam hal ini sebagai salah satu bentuk tindak pidana korupsi dapat dikategorikan sebagai

\footnotetext{
${ }^{15}$ Andi Hamzah, Pemberantasan Korupsi melalui Hukum Pidana Nasional dan Internasional, Raja Grafindo Persada, Jakarta, 2005, h. 3
} 
tindak pidana khusus, karenanya tindak pidana korupsi diatur dalam Undang-Undang tersendiri dengan ketentuan dan mekanisme khusus.

Pemberian hadiah atau gratifikasi dapat dikategorikan tindak pidana dengan mengacu pada aturan yang terdapat dalam Pasal 12 B dan 12 C Undang-Undang Nomor 20 Tahun 2001 tentang Pemberantasan Tindak Pidana Korupsi (Tipikor), dalam hal ini dipersamakan dengan suap, apabila berhubungan dengan jabatan dan yang berlawanan dengan kewajiban atau tugasnya. Dengan demikian jika gratifikasi tidak berhubungan dengan jabatan dan yang berlawanan dengan kewajiban atau tugasnya, gratifikasi tersebut adalah perbuatan yang sah menurut hukum.

Dalam ketentuan pengaturan terkait dengan gratifikasi pelayanan seksual yang ada tidak menyebutkan secara eksplisit perihal ketentuan pidana terhadap gratifikasi pelayanan seksual. Namun jika menelaah beberapa ketentuan terkait, baik pidana materil maupun formil, akan terlihat beberapa ketentuan hukum pidana yang sebenarnya sudah cukup kuat untuk menjerat pelaku gratifikasi pelayanan seksual .

Berdasarkan interpretasi historis pemberian hadiah berupa layanan seks sebagai gratifikasi sesuai dengan tujuan dibuatnya Undang-Undang Nomor 20 Tahun 2001 tentang Perubahan Undang-Undang Nomor 31 Tahun 1999 tentang Pemberantasan Tindak Pidana Korupsi. Sesuai dengan pengertian penafsiran historis atau sejarah yaitu penafsiran dengan cara menganalisa sejarah peraturan perundang-undangan sehingga dapat diketahui tujuan atau maksud pembuatannya. ${ }^{16}$ Tujuan diterbitkannya aturan atau undang-undang tentang pemberantasan tindak pidana korupsi adalah untuk mencegah dan memberantas tindak pidana korupsi.

Adapun berdasarkan interpretasi ekstensif yaitu penafsiran yang dilakukan dengan cara memperluas arti kata-kata yang terdapat dalam

${ }^{16}$ Ishaq, Dasar-Dasar Ilmu Hukum, Sinar Grafika, Jakarta, 2012, h. 256 
peraturan undang-undang sehingga suatu peristiwa dapat dimasukkan ke dalamnya. ${ }^{17}$ Dalam hal ini defenisi layanan seksual dapat dimasukkan ke dalam kata " fasilitas lainnya".

Pegawai Negeri dan Penyelenggara Negara yang melakukan tindak pidana korupsi dalam hal menerima gratifikasi pelayanan seksual dapat dijerat pasal 5 ayat (2), pasal 12 huruf a dan b, atau pasal 12B UndangUndang Nomor 31 Tahun 1999 juncto Undang-Undang Nomor 20 Tahun 2001 bila mana memenuhi unsur unsur sebagaimana dimaksud .

Adapun bagi si pemberi gratifikasi dapat dijerat pasal 5 ayat (1) Undang-Undang Nomor 31 Tahun 1999 juncto Undang-Undang Nomor 20 Tahun 2001

Undang- Undang Pemberantasan Tindak Pidana Korupsi sudah sangat jelas mengatur tentang sanksi yang dapat dikenakan kepada pelaku pemberi dan penerima gratifikasi . tetapi dalam hal gratifikasi pelayanan seksual undang-undang tersebut belum mengatur sanksi terhadap pihak ketiga dalam hal ini "perempuan" sebagai pemberi layanannya.

Perlunya mengenakan sanksi hukum bagi perempuan pemberi layanan seksual ini, karena ia dianggap sebagai orang yang turut serta dalam tindak pidana gratifikasi pelayanan seksual yang telah ikut serta mendukung terjadinya praktek gratfikasi seksual dan merusak moral serta citra bangsa ini.

Dalam beberapa kasus perempuan pemberi layanan seksual ini juga adalah orang yang berkepentingan langsung dengan pegawai negeri atau penyelenggara negara sebagai penerima gratifikasi seksual .

Sanksi pidana yang tepat bagi "perempuan pemberi layanan seks “ sekaligus orang yang berkepentingan langsung dapat dijerat pasal 5 ayat (1) Undang-Undang Pemberantasan Tindak Pidana Korupsi. Adapun sanksi pidana yang bisa dikenakan kepada obyek hukum gratifikasi

${ }^{17}$ Chainur Arrasjid, Dasar-Dasar Ilmu Hukum, Sinar Grafika, 2000, h. 93. 
seksual (perempuan pemberi layanan seks) dapat dijerat dengan pasal 15 , yaitu "setiap orang yang melakukan percobaan, pembantuan atau pemufakatan jahat untuk melakukan tindak pidana korupsi, dipidana dengan pidana yang sama sebagaimana dimaksud pasal 2, pasal 3, pasal 5 sampai dengan pasal 14 “. Pengenaan pasal ini dianggap sesuai karena dalam hal ini "perempuan pemberi layanan seks" tersebut dianggap melakukan "pembantuan" dan "pemufakatan" untuk memudahkan dan memperlancar terjadinya tindak pidana korupsi gratifikasi seksual tersebut.

\section{E. PENUTUP}

1. Kesimpulan

a. Rumusan pasal -pasal dalam Undang-Undang Nomor 31 Tahun 1999 juncto Undang-Undang Nomor 20 Tahun 2001 Tentang Pemberantasan Tindak Pidana Korupsi masih kurang jelas dan tegas mengatur tentang aspek-aspek gratifikasi khususnya gratifikasi seksual baik dari sisi pembuktian maupun sanksi pidana . Namun demikian pelayanan seksual sebagai salah satu bentuk gratifikasi dapat dikategorikan sebagai tindak pidana korupsi dengan mengacu kepada penjelasan pasal $12 \mathrm{~B}$ ayat (1) Undang-Undang Nomor 31 Tahun 1999 juncto Undang -Undang Nomor 20 Tahun 2001 tentang Pemberantasan Tindak Pidana Korupsi yang menyebutkan bahwa :

"Yang dimaksud dengan gratifikasi dalam ayat ini adalah pemberian dalam arti luas yakni meliputi pemberian uang, barang, rabat (discount), komisi, pinjaman tanpa bunga, tiket perjalanan,fasilitas penginapan, perjalanan wisata, pengobatan Cuma-Cuma dan fasilitas lainnya. Gratifikasi tersebut baik yang diterima di dalam negeri maupun di luar negeri dan yang dilakukan dengan menggunakan sarana elektronik atau tanpa sarana elektronik".

Pelayanan seksual dapat dikategorikan dalam kata "fasilitas lainnya". Gratifikasi pelayanan seksual dapat berubah menjadi suatu 
perbuatan yang dianggap suap dan merupakan tindak pidana korupsi apabila gratifikasi tersebut memenuhi unsur pegawai negeri atau penyelenggara Negara dan berhubungan dengan jabatannya dan yang berlawanan dengan kewajiban atau tugasnya .

b. Dasar - dasar hukum pembuktian dalam tindak pidana korupsi terkait dengan gratifikasi, pembalikan beban pembuktian gratifikasi pelayanan seksual dapat merujuk pada pengenaan pembuktian pasal 12 B Undang-Undang Nomor 20 Tahun 2001. Pembuktian gratifikasi seksual bisa melalui kesaksian atau alat bukti lainnya.

Pegawai Negeri dan Penyelenggara Negara yang melakukan tindak pidana korupsi dalam hal menerima gratifikasi pelayanan seksual dapat dijerat pasal 5 ayat (2), pasal 12 huruf a dan b, atau pasal 12 B Undang-Undang Nomor 31 Tahun 1999 juncto UndangUndang Nomor 20 Tahun 2001 bila mana memenuhi unsur unsur dalam peraturan perundang-undangan tersebut. Demikian juga bagi si pemberi dan "perempuan" yang menjadi obyek layanan seksual dapat dijerat dengan pasal 5 ayat (1), pasal 15 Undang-Undang Nomor 31 Tahun 1999 juncto Undang-Undang Nomor 20 Tahun 2001 Tentang Pemberantasan Tindak Pidana Korupsi. Bagi pelaku juga dapat dikenakan sanksi pidana dalam pasal 284 KUHP mengenai delik kesusilaan jika memenuhi unsur-unsur yang dimaksud dalam pasal tersebut.

\section{Saran}

a. Diharapkan kepada pemerintah untuk bersama-sama baik unsur legislatif, eksekutif maupun judikatif untuk merumuskan dan meregulasikan formulasi yang jelas tentang aspek gratifikasi dalam Undang-Undang Nomor 31 Tahun 1999 juncto Undang-Undang Nomor 20 Tahun 2001 Tentang Pemberantasan Tindak Pidana 
Korupsi khususnya aspek tentang gratifikasi seksual . Begitupun dalam penjelasan pasal 12 B yang dimaksud "fasilitas lainnya" bisa lebih diperjelas dengan menambahkan beberapa item termasuk fasilitas "pelayanan seksual".

b. Diperlukan kajian lebih lanjut dan tepat untuk merumuskan dan memformulasikan ketentuan dan aturan yang berkenaan dengan pembuktian dan pengenaan sanksi hukum bagi pelaku gratifikasi pelayanan seksual.

Ketentuan perundang-undangan dengan pidana dan sanksi yang berat dapat menjadi langkah untuk mencegah dan dapat menanggulangi kasus Gratifikasi pelayanan seksual tersebut. Kasus gratifikasi layanan seksual dapat saja berkembang tidak hanya sebatas hubungan antara laki-laki dan perempuan tapi bisa saja dengan munculnya penyakit-penyakit kelainan seksual dapat terjadi hubungan antara laki-laki dengan laki -laki atau sebaliknya perempuan dengan perempuan.

\section{DAFTAR BACAAN}

Arrasjid, Chainur, Dasar-Dasar Ilmu Hukum, Sinar Grafika, 2000

Chaerudin, S.H, M.H, Syaiful Ahmad Dinar,S.H,M.H dan Syarif Fadillah,S.H,M.H, Strategi Pencegahan dan Penegakan Tindak

Pidana Korupsi, Refika Aditama, Bandung, 2008.

Chazawi, Adami, Hukum Pidana Korupsi Di Indonesia, Edisi Revisi 
Raja Grafindo Perkasa, Jakarta, 2016.

Hukum Pembuktian Tindak Pidana Korupsi, Alumni, Bandung, 2006.

Doni Muhardiansyah et al, Buku Saku: Memahami Gratifikasi, Cet. Ke-1, Komisi Pemberantasan Korupsi, Jakarta, 2010.

Hamzah, Andi, Perbandingan Hukum Pidana Beberapa Negara. Cetakan Ketiga, Sinar Grafika, Jakarta, 2012

, Pemberantasan Korupsi Melalui Hukum Pidana

Nasional Dan Internasional, Cetakan Keenam, Raja Grafindo

Perkasa, Jakarta, 2014

, Delik-Delik Tertentu (Speciale Delicten) di Dalam KUHP,

Edisi Kedua, Sinar Grafika, Jakarta.2015

Hardy, Gail , "Kebutuhan Perempuan dalam Interaksi Sosial: Suatu Masalah

Perempuan dalam Heterogenitas Kelompoknya", dalam Perempuan

dan Politik Tubuh Fantastis, Kanisius, Yogyakarta, 1998

Ishaq, Dasar-Dasar Ilmu Hukum, Sinar Grafika, Jakarta, 2012

Komisi Pemberantasan Tindak Pidana Korupsi, Buku Saku Memahami Untuk Membasmi, KPK, Jakarta, 2014

Komisi Pemberantasan Tindak Pidana Korupsi, Buku Saku Memahami Gratifikasi, KPK, Jakarta, 2014

Komisi Pemberantasan Tindak Pidana Korupsi, Pedoman Pengendalian Gratifikasi, KPK, Jakarta, 2015

Lembaga Adminstrasi Negara, Modul Diklat Prajabatan Percepatan Pemberantasan Korupsi, LAN, Jakarta, 2009

Lembaga Adminstrasi Negara, Modul Diklat Prajabatan Anti Korupsi, LAN, Jakarta, 2014

Ramadhan KH dan Abrar Yusra, Hoegeng : Polisi Idaman dan Kenyataan, Sinar Harapan, Jakarta, 1994

Saya Perempuan Anti Korupsi (SPAK), Buku Panduan Game SPAK, Mengenal Korupsi, AIPJ, Jakarta, 2015.

Tim Penulis Buku Pendidikan Anti Korupsi, Pendidikan Korupsi Untuk Perguruan Tinggi, Anti Korupsi, Kementerian Pendidikan dan 
Kebudayaan RI, Direktorat Jenderal Pendidikan Tinggi, Bagian Hukum Kepegawaian, Jakarta, 2011 